\title{
The influence of Problem-based Learning and Motivation on Students' Learning Outcomes
}

\author{
Helmi Linda ${ }^{1}$, Z. Mawardi Effendi ${ }^{2}$, Idris ${ }^{3}$ \\ ${ }^{1}$ Faculty of Economics, Universitas Negeri Padang, Padang, Indonesia \\ $\square$ (e-mail) helmilinda73@yahoo.co.id \\ ${ }^{2}$ Dept. of Economics Education, Faculty of Economics, Universitas Negeri Padang, Padang, Indonesia \\ $\triangle$ (e-mail) zmeffendi@gmail.com \\ ${ }^{3}$ Dept. of Economics, Faculty of Economics, Universitas Negeri Padang, Padang, Indonesia \\ $\triangle$ (e-mail) idris_unp@yahoo.co.id
}

\begin{abstract}
The aim of the study is to determine the influence of teaching method on students' learning outcomes, motivation and their interaction on students' learning outcomes. The population on this study was 199 accounting students in grade XI at SMK Negeri 1 Painan. The sample was selected using purposive sampling technique resulted with 57 students. This study collected data by using a survey questionnaire. The data were analyzed using two-ways ANOVA. The results of the study indicate that students' using problem-based learningmethod have significantly higher outcomes than using conventional learning method. Further, students with high motivation have higher learning outcomes than students who have low motivation. Finally, there is no interaction between the use of problem based learning method and motivation on students' learning outcome for accountancy subject.
\end{abstract}

Keywords: problem-based learning method, conventional learning method, motivation, and learning outcomes

\section{Introduction}

Education has a goal to produce graduates with cognitive, affective, and psychomotor abilities. One way to assess the education quality is by measuring the students' learning outcomes. A preliminary study was conducted and reveals a low students' performance at SMK N 1 Painan. Around $28.57 \%$ of students' learning outcomes was below the minimum standard performance required by the school. It means that there are issues in students' learning at SMKN 1 Painan that hinder them from reaching their maximum achivement.

There are factors influencing learning outcomes, such as students and teachers. For the case of SMKN 1 Painan, th epreliminary study shows that the low students' learning results were caused by the students themselves. Indeed, they tend to be passive, unresponsive, and silent during the learning process in the classroom. The students in such a condition is called as an object, and it could be monotonous in learning process. Anoth epossible reason for the students' low performance was the teacher's preaching method.

To overcome the case above, a teacher as an educator should understand the students' needs especially when delivering materials and. An appropriate learning method which is suitable to the aim of learning is very important. The problem-based learning method is able to upgrade students' learning outcome at at SMK Negeri 1 Painan.

Problem-based learning method is going to make easier the students to understand the material because it's cammon material to discuss which is related to organization form.Most ofmaterial is really familiar and often to be met in daily life such as economic enterprise, concept, and principles in order to students are able to compare the material in the field and theory indeed. After several comparison the researcher decide to use the problem based learning method and it the most suitable for this study. 
According to Rusman (2012: 74), problem based learning is using matter in reallity, learning is focused on problem solving, learning objectives determined by the students, and teachers act just as facilitator.

The previously researchers have been examined using of problem-based learning method and its influence by learning outcomes. Erdogan and Senemuglu (2014) had find that model of problem-based learning is effective to improve and upgrade academic skills. Gorghiu et al. (2015) find the problembased learning method is able to increase students' comprehension and capability to understand the meaning and the concept of science and learning. According to Anggraini et al. (2013) and Sari (2015) said that problem based learning method is able to upgrade and increase students' learning outcomes to understand the concept of knowledge itself.

The results of learning are influenced by motivation of study immediately and the exact method that is implemented at school when learning process going on. The students are more spiritful to study, do more and better in attitude by motivation them all. Motivation in education not only an important thing but also could upgrade the students' learning outcome and make it the students more enjoy studying (Anni, 2006: 157). Historically, the teachers due understand whenthe students need to be motivated during the learning process in order to students more fun in learning, more communicative, less worry, and increase students' creativity and learning activity.

Motivation in learning is crucial and essential aspect to upgrade the students' learning outcomes. On the previous observation it can be concluded that the students have great spirit to do their homework actually, but about $70 \%$ they cheat to their friend. It means there are so many students tocheat each others and less motivation to find the way out of the cases. At the fact that after the students study at school, it's so rare for them to review the lesson at home in order to students are more difficult to understand the material well.

A number of previous studies have examined the influence of motivation on students' learning outcomes. Taurian (2015) researches about the influence of students' motivation and their impact on the quality of education. The results show that teachers must pay attention to the students' motivation in order to get better results and to upgrade the education quality. Ryan and Decci (2000) examine intrinsic and extrinsic aspects of motivation. The results show that intrinsic motivation is needed in education. Students that is influenced by intrinsic motivation will show improvement in their academic performance. Fortune (2010) states that motivation to learn have a significant influence on students' learning outcomes.

The hypotheses formulated for this study are as follows.

$\mathrm{H}_{1}$ Students who are taught by using problem-based learning method have a significantly higher learning outcomes than those who are taught by conventional method

$\mathrm{H}_{2}$ Students with high motivation have significantly higher learning outcomes compared to students with low learning motivation

$\mathrm{H}_{3}$ There is a significant interaction between learning method and students' motivation on students' learning outcomes

\section{Methods}

The types research of the study is classified based on quasi-experimental. This study used quantitative experimental approach in order to organize two factorial designs. This research was conducted at SMK Negeri 1 Painan with total population of 199 students at class XI. By using purposive sampling technique, this study selected a sample of 57 students which consist of 32 students in class XI AKT 2 (experimental group) and 27 students in class XI ADP 1(control group).

To obtain information about the impact of problem-based learning method on learning outcomes, data and information were obtained through tests and questionnaires. The students learning outcomes is devided into 2 groups, namely, exsperimental and control classes. The students' motivation is measured and grouped into two, the students who has high motivation in learning and students' low 
motivation. Two-way ANOVA was used to analyze the effect of problem-based learning versus and conventional methods in learning process and motivation on learning outcomes.

\section{Results and Discussion}

The results of descriptive analysis show that students in both experiment and control classes have comparable learning motivation in 'good' category. The assessment can be seen from the TCR motivation to learn at experimental class $73.62 \%$ and $74.73 \%$ at control group. Although the students' motivation in control class higherthan experiment group, the result and the criteria both of the groups are still samewhich is pretty good criteria. It means the whole students at both clasess the experimental and control classes had a pretty good motivation to learn. Therefore, to obtain and achive better students' learning outcomes, the students should have high motivation to learn by doing tasks independently and eliminate cheating behavior.

The first hypothesis proposed that the learning outcomes of students who are taught by using problem-based learning method is significantly higher than those who are taught by conventional method. The results of data analysis show that students' learning outcomes in the exerimental class is significantly higher than the control group, with a significance level of 0.026 which is lower than alpha 0.05 . It means that $\mathrm{H}_{1}$ is suppported. It could be concluded that students performance is significantly improved by using problem-based learning method compared to students who were taught by conventional method.

The second hypothesis proposed that accounting students who have high learning motivation have significantly higher learning results than students who have low learning motivation. The results of hypotheses support that students with high learning motivation show significantly higher learning results compared to students with low learning motivation. The resuls show a significance level of 0.001 which is lower than alpha 0.05 . It means that $\mathrm{H}_{2}$ is supported. Thus, students who have high motivation to learn experience better grades than students with low learning motivation.

The third is hypothesis proposed that there is a significant interaction and relation between learning method used and students' motivation on students' learning results. It could be known the hypothesis of motivation level significantly $0.425>0.05$. It means that $\mathrm{H}_{3}$ is not supported. It could be concluded that the interaction between learning outcomes and learning motivation is not significant. It means that learning model does not influence students' motivation in improving their learning outcomes, and learning motivation does not affect to learning model to improve students' learning outcomes.

The results show that the implementation of problem-based learning on accounting students of at class XI at SMKN 1 Painan has significantly upgraded the students' learning outcomes, compared to the results from conventional learning method. The ANOVA results show a significantly value of 0.026 which is lower than alpha 0.05 . It means that problem-based learning model significantly influence students' learning outcomes. In another words, problem-based learning model is more effective to improve students' learning outcomes compared to the conventional model.

Students who have high motivation in learning get significantly higher results than students who have low learning motivation. The results of two-ways ANOVA show a significant value of 0.001 which is lower than alpha 0.05. It's means students who have high learning motivation will obtain higher learning outcomes when compared with students who have low motivation in learning. In other words, the students who want to improve their learning performance must have a high motivation to learn.

To determine the interaction between the implementation of learning models and students' motivation toward learning outcomes can be done by looking at a significant two-way ANOVA analysis. It means obtain significant value $0.425>0.05$. it could be concluded that there is no interaction between learning models and learning motivation to influence students' learning outcomes accounting subject at SMK N 1 Painan. Both of method of learning and motivation in learning do not influence each others to students' learning result because learning mothode due has a great effect to result of 
learning if the students do their work independetly, the such a model is good implemeted to learning group who has low motivation in studying.

Additional analysis was conducted to ensure there is no influence of the interaction between the learning method used and students' learning motivation on students' learning outcomes. The additional output of two-ways ANOVA was utilized particularly by comparing the means of each group and the intersection lines to figure out the estimated marginal means of students' learning outcomes. It can conclude the influence of two variables, learning method and motivation to learn only influence students' learning outcomes partially. It supported that there is no interaction between learning method and learning motivation.

\section{Conclusions}

This study aims to examine the influence of teaching method on students' learning outcomes, motivation and their interaction on students' learning outcomes. The population on this study was 199 accounting students in grade XI at SMK Negeri 1 Painan. The sample was selected using purposive sampling technique resulted with 57 students. This study collected data by using a survey questionnaire. The data were analyzed using two-ways ANOVA.

Several important results of the study are as follows. First, students' learning outcomes using problembased learning is significantly higher than those using conventional learning method. It prove that the implemetation of problem-based learning method helps students to understand the subject clearly in order to increase their learning outcomes. Second, students who have high learning motivation have significantly higher learning outcomes than students who have low learning motivation. Finally, there is no interaction between the use of problem based learning method and motivation on students' learning outcome for accounting subject. The results show that problem-based learning method is effective for students with low learning motivation in order to improve their performance in accounting subjects.

\section{References}

Anggraini, Vebriyanti Dwi, at al. (2013). Problem-based leaning, motivasi belajar, kemampuan awal, dan hasil belajar siswa SMK. Jurnal Ilmu Pendidikan, 19(2), 187-195.

Anni, Catharina Tri, (2006). Psikologi Belajar.Universitas Negari Semarang Press: Semarang.

Endogan, Tolgadan N.S. (2014). Problem-based learning in teacher education: Its promises and challenges. Procedia - Social and Behavioral Sciences, 116, $459-463$.

Gorghiu, Gabriel, et.al. (2015). Problem-based learning-An efficient learning strategy in the science lessons context. Procedia - Social and Behavioral Sciences, 191, 1865 - 1870.

Rejeki, Sri. (2010). Pengaruh kondisi ekonom keluarga, motivasi belajar, dan gaya belajar terhadap hasil belajar siswa. Pendidikan Administrasi Perkantoran, 1(1).

Rusman. (2012). Strategi Pembelajaran Dengan Problem based learning ItuPerlu. Bogor: Ghalia Indonesia.

Ryan, Richard M dan Edward L.Deci.( 2000). Intrinsic and extrinsic motivations: Classic definitions and new directions. Contemporary Educational Psychology, 25,54-67.

Sari, Dewi Tinjung, at al. (2015). Penerapan model PBL untuk meningkatkan kemampuan berpikir kritis dan hasil belajar siswa pada materi ekonomi di SMA Negeri 3 Surakarta tahun pelajaran 2014/2015. Jurnal Ilmu Pendidikan.

Taurina, Zane. (2015). Students' motivation and learning outcomes: significant factors in internal study quality assurance system. International Journal for Cross-Disciplinary Subjects in Education (IJCDSE), 5(4). 